\title{
APPLICABIIITY OF THE CALIFORNIA GUEST STATUTE TO SHARE-THE-EXPENSE MOTOR TRIPS
}

Under the common law, the driver or owner of an automobile-owes a duty of ordinary care to occupants of his car, and is liable to them for injury proximately caused by his ordinary negligence. A majority of twentynine of fifty-one American jurisdictions have discarded this duty of ordinary care toward gratuitous occupants. ${ }^{1}$ The California "guest statute" provides:2

No person who as a guest accepts a ride in any vehicle upon a highway without giving compensation for such ride, nor any other person, has any right of action for civil damages against the driver of such vehicle or against any other person legally liable for the conduct of such driver on account of personal injury to or the death of such guest during such ride, unless the plaintiff in any such action establishes that such injury or death proximately resulted from the intoxication or wilful misconduct of said driver.

Though the statute abolishes the common law duty of ordinary care toward a guest, it does not affect the duty owed a passenger. The fact of compensation is the distinguishing factor, ${ }^{3}$ and the status of a rider as passenger or guest determines his right of recovery for injury resulting from ordinary neghigence of the driver.

The California courts have tended to narrow the guest classification by defining compensation in broad terms. ${ }^{4}$ But some form of tangible benefit

1 Twenty-seven states have "guest statutes." These follow the general form of denial of a right of action to a gratuitous occupant with exceptions where the driver's conduct is so blameful as to allow an action. The most common exceptions are: intent; intoxication; gross negligence; or willful, reckless, heedless, wanton misconduct or negligence. These states are: Alabama, ArA. CoDE ANN. tit. 36, § 95 (1940); Arkansas, ARK. STAт. \$§ 75-913, 914, 915 (1947) ; California, CaI. Verr. Code \$ 403; Colorado, Colo. Rev. Srat. ANn. \$ 13-9-1 (1953); Delaware, DEL. Code ANn. tit. 21, $\$ 6101$ (1953); Florida, FLA. STAT. $\$ 320.59$ (1949); Idaho, IDAHo CODE ANn. \$ 49-1001 (1947); Illinois, InI. REv. STax. c. 951/2, § 58a (1953); Indiana, IND. ANn. Stat. \$ 47-1021 (Burns 1952); Iowa, Iowa Code $\$ 321.494$ (1954); Kansas, Kan. Gen. Stat. ANn. \$ 8-112b (1949); Michigan, MICI. Comp. Laws \$ 256.29 (1948); Montana, Monx. Rev. Code ANn. §32-1113 (1947); Nebraska, Neb. Rev. Stat. \$39-740 (1943); Nevada, Nev. Courp. Laws \$ 4439 (Supp. 1941) ; New Mexico, N. M. Stat. Ann. § 64-24-1 (1953); North Dakota, N. D. Rev. Code \$ 39-1501-03 (1943) ; Ohio, OHIo Rev. Code ANN. \$ 4515.02 (Baldwin 1953); Oregon, Ore. Rev. Sxat. \$30.110 (1953); South Carolina, S.C. Code \$ 46-801 (1952); South Dakota, S. D. Code \$ 44.0362 (1939); Texas, Tex. Rev. Crv. StaT. art. 6701b, § 1 (1948); Utah, UTAF Code ANn. § 41-9- (1953); Vermont, VT. REv. Stat. \$ 10223 (1947); Virginia, VA. CODE ANN. \$ 8-646.1 (1950); Washington, Wast. Rev. Code \$ 46.08.080 (1951); Wyoming, Wyo. CoMr. STAт. ANN. \$60-1201 (1945). In addition, Georgia and Massachusetts reach the same result without a guest statute: Slaton v. Hall, $168 \mathrm{Ga}$. 710, 148 S.E. 741 (1929); Welts v. Caldwell, 120 N.E.2d 280 (Mass. 1954). The remaining states plus Alaska, the District of Columbia and Hawaii have a common law rule.

2 CAI. VEH. CODE $\$ 403$.

3 Whitmore v. French, 37 Cal.2d 744, 235 P.2d 3 (1951) ; Kruzie v. Sanders, 23 Cal.2d 237, 143 P.2d 704 (1943).

4 Prager v. Isreal, 15 Cal.2d 89, 98 P.2d 729 (1940). But cf. Kruzie v. Sanders, 23 Cal.2d 237, 143 P.2d 704 (1943), where the court said that the guest statute must be interpreted in accordance with the intent of the legislature. 
must accrue to the driver. ${ }^{5}$ Compensation has been found to exist where a clear agreement to pay for the ride has been shown, ${ }^{6}$ or a special relationship exists which implies a benefit to the driver. ${ }^{7}$ If the parties have a mutual purpose, ${ }^{8}$ be it busmess ${ }^{9}$ or social, ${ }_{10}^{10}$ or if the rider accompanies the driver as an accommodation to the latter, ${ }^{11}$ the rider will be considered a passenger.

Generally, where a tangible benefit conferred on the driver is motivation for his furmshing the transportation, compensation will be found. Merely paying a portion of the expense, however, may be incidental and does not necessarily constitute compensation, ${ }^{12}$ and the existence of a previous passenger relationship will not preclude the formation of a guest-host relationship by a change of circumstances. ${ }^{13}$

Whether a rider was a guest or a passenger is a question of fact, ${ }^{14}$ and unless the evidence is such as to permit no other inference, ${ }^{15}$ it is for the jury to decide. ${ }^{16}$ The burden of proof of passenger status is on the plaintiff. ${ }^{17}$

A situation often litigated is that of the motor trip in which several persons agree to share the expenses, and travel in an automobile belonging to one of them. Since such an agreement has factors both of a benefit conferred upon the owner as compensation and social reciprocity, which does not amount to compensation, it is not easily classified.

Formerly the California courts in applying the tangible benefit test of compensation to this type of case made a distinction based on the purpose

\footnotetext{
5 For a detailed outline and discussion of compensation in the California cases see Comment, 26 CALIF. L. REv. 251 (1938). See also Annot., 10 A.L.R.2d 1351 (1950).

6Martinez v. Southern Pac. Co., 132 A.C.A. 237, 281 P.2d 537 (1955); Jenkins v. National Paint \& Varnish Co., 17 Cal. App.2d 161, 61 P.2d 780 (1936).

7 Thompson v. Lacey, 42 Cal.2d 443,267 P.2d 1 (1954) (employees of a mutual employer); Follansbee v. Benzenberg, 122 Cal. App.2d 466, 265 P.2d 183 (1954) (driver-vendor and plaintiff-customer) ; Clifford v. Ruocco, 39 Cal.2d 327, 246 P.2d 651 (1952) (landlord-driver furnished plaintiff-tenant transportation to and from her place of employment); Davis v. Woodcock, 101 Cal. App.2d 618, 225 P.2d 918 (1951) (driver was supplied with gas and oil by his employer to drive himself and another employee to work); Riley v. Berkeley Motors, Inc., 1 Cal. App.2d 217, 36 P.2d 398 (1934) (driver-vendor and plaintiff-customer, regardless of who drives).

8 Harris v. Harfmann, 113 Cal. App.2d 615, 248 P.2d 501 (1952).

9 Walker v. Adamson, 9 Cal.2d 287, 70 P.2d 914 (1937); Fachadio v. Krovitz, 62 Cal. App.2d 362, 144 P.2d 646 (1944).

10 Whitmore v. French, 37 Cal.2d 744, 235 P.2d 3 (1951).

11 Kohle v. Sinnett, 118 Cal. App.2d 126, 257 P.2d 483 (1953); Christiana v. Rattaro, 81 Cal. App.2d 597, 184 P.2d 682 (1947).

12 Whitmore v. French, 37 Cal.2d 744, 235 P.2d 3 (1951) ; McCann v. Hoffmann, 9 Cal.2d 279, 70 P.2d 909 (1937) ; Brandis v. Goldanski, 117 Cal. App.2d 42, 255 P.2d 36 (1953).

13 Lyon v. City of Long Beach, 92 Cal. App.2d 472, 207 P.2d 73 (1949).

14 Follansbee v. Benzenberg, 122 Cal. App.2d 466, 265 P.2d 183 (1954); Koble v. Sinnett, 118 Cal. App.2d 126, 257 P.2d 483 (1953); DaVall v. Cary, 115 Cal. App.2d 378, 252 P.2d 42 (1953).

15 Whitunore v. French, 37 Cal.2d 744, 235 P.2d 3 (1951).

16 Follansbee v. Benzenberg, 122 Cal. App.2d 466, 265 P.2d 183 (1954); Kohle v. Sinnett, 118 Cal. App.2d 126, 257 P.2d 483 (1953) ; DaVall v. Cary, 115 Cal. App.2d 378, 252 P.2d 42 (1953).
}

17 Malloy v. Fong, 37 Cal.2d 356, 232 P.2d 241 (1951); Follansbee v. Benzenberg, 122 Cal. App.2d 466, 265 P.2d 183 (1954). 
of the trip. Where the trip was for some economic or non-social purpose, the agreement to share the expenses (the tangible benefit) was considered to be compensation and not a mere social amenity. The rider was a passenger. ${ }^{18}$ If, however, the trip was social in nature, the agreement to share expenses was considered purely an exchange of the common courtesies of the road and the status of the occupants was that of host and guest. ${ }^{19}$ In McCann v. Hoffman the court stated the law as follows: ${ }^{20}$

[W] here a special tangible benefit to the defendant was the motivating influence for furnishimg the transportation, compensation may be said to have been given. But it is not given where the main purpose of the trip is the joint pleasure of the participants. The payment of a portion of the expense ... is inerely imcidental and does not constitute the inoving influence for the transportation. The provocation for the offer of transportation remains the joint social one of reciprocal hospitality or pleasure.

Thus, the share-the-expense social trip was excluded from the tangible benefit rule of compensation by deducing from the social nature of the trip a purely social motivation. ${ }^{21}$ Other jurisdictions faced with a similar problem under a guest statute have not made this distinction. ${ }^{22}$

This refinement, however, was obliterated by the decision in Whitmore v. French in which the court said: ${ }^{23}$

[I] $t$ has been held that the sharing of expenses does not destroy the host and guest relationship if nothing more is involved than the exchange of social amenities and reciprocal hospitality. [Citing McCann v. Hoffman.] Where, however, the driver receives a tangible benefit, monetary or otherwise, which is $a$ inotivating influence for furnishing the transportation, the rider is a passenger and the driver is liable for ordinary neghigence. [Citing cases.] This is, of course, true whether the trip is for the joint pleasure of participants or is of a non-social nature.

\footnotetext{
18 Walker v. Adamson, 9 Cal.2d 287, 70 P.2d 914 (1937). Here the plaintiff and defendants jointly owned summer cottages, which they rented, sharing expenses and incoune equally. They made a number of trips each year to the property, using their cars alternately. The plaintiff was injured on one of these trips due to defendant's ordinary negligence. Plaintiff had given defendant money to defray the cost of the trip. Held: the parties were engaged in a business venture for their inutual advantage, and the plaintiff had thus given compensation. See Jensen v. Hanse, 12 Cal. App.2d 678, 55 P.2d 1201 (1936), where three appraisers made joint use of an automobile to inspect and appraise property. Held: a passenger relationship.

19 McCann v. Hoffinan, 9 Cal.2d 279, 70 P.2d 909 (1937) ; Fiske v. Wilkie, 67 Cal. App.2d 440, 154 P.2d 725 (1945); Stephen v. Spaulding, 32 Cal. App.2d 326, 89 P.2d 683 (1939); Rogers v. Vreeland, 16 Cal. App.2d 364, 60 P.2d 585 (1936). In the McCann case, two couples went on a pleasure trip, sharing expenses without a prior agreement other than an understanding from previous trips of like nature. Held: the sharing of the cost of gasoline and oil on a pleasure trip (a social and nonbusiness purpose) is merely the exchange of social amenities and does not create a passenger status.

209 Cal.2d 279, 286, 70 P.2d 909, 913 (1937). (Emphasis added.) See note 19 sutpra.

21 See Comment, 26 CAIIF. L. REV. 251 (1938), for a discussion adverse to this rule.

22 Dorn v. North Olmsted, 133 Ohio St. 375, 14 N.E.2d 11 (1938); Beer v. Beer, 52 Ohio App. 276, 3 N.E.2d 702 (1935) ; Kerstetter v. Elfman, 327 Pa. 17, 192 Atl. 663 (1937); Alexiou v. Nockas, 171 Wash. 369, 17 P.2d 911 (1933).

2337 Cal.2d 744, 746, 235 P.2d 3, 5 (1951). (Emphasis added.)
} 
Thus, by a clear holding, the California Supreme Court removed from the social trip the presumption that any sharing of expenses was only reciprocal hospitality and applied the tangible benefit motivation test equally to social and non-social situations. The factual situations of the McCann and Whitmore cases were similar. In both cases two couples were taking a trip and sharing expenses. The main factual distinction was that the trip in the Whitmore case was of greater duration, and the defendants' two children were accompanying the adults. Since the Whitmores and Frenches were sharing all expenses of the trip equally, the plaintiffs were paying for one-half of the expenses of the defendants' children. The majority held this to be more than simple social reciprocity, saying that no other reasonable inference could be drawn from the evidence and that the trial judge correctly decided the question as a matter of law. Two justices dissented on the ground that it was a question for the jury. Later cases have followed the Whitmore decision, ${ }^{24}$ and the effect is to narrow again the application of the guest statute by allowing the tangible benefit rule to apply fully in social journey cases.

Interesting to note is an inconsistency in the wording of the tangible benefit rule. Under the $M c C a n n$ wording the tangible benefit had to be the motivating influence for it to be compensation, whereas according to the Whitmore wording the tangible benefit is compensation if it is $a$ motivating influence. Obviously (expecially in the situation of friends and relatives, where this type of case usually occurs) the use of " $a$ " rather than "the" may make a significant difference, the latter being more restrictive. Two alternative explanations for the change in wording suggest themselves. Either it was unwitting, the court in the Whitmore case wishing to adopt the existing McCann wording of the tangible benefit rule and not intending to narrow further the application of the guest statute; or it was intentional, the court desiring to widen the scope of the tangible benefit test.

In Clifford v. Ruocco ${ }^{25}$ eleven months after the Whitmore case, the court ${ }^{26}$ used the $M c C a n n$ wording in a footnote. ${ }^{27}$ From this it may be inferred that there was no intention on the part of the court to change the tangible benefit rule as enunciated in the McCann decision. On the other hand, the majority of the later cases in point use the Whitmore wording, ${ }^{23}$ all but one of such majority quoting the Whitmore case.

24 Thompson v. Lacey, 42 Cal.2d 443, 267 P.2d 1 (1954); Clifford v. Ruocco, 39 Cal.2d 327, 246 P.2d 651 (1952); Kroiss v. Butler, 129 Cal. App.2d 550, 277 P.2d 873 (1954); Brandis v. Goldanski, 117 Cal. App.2d 42, 255 P.2d 36 (1953).

2539 Cal.2d 327, 246 P.2d 651 (1952).

26 Chief Justice Gibson was the author of both the Whitmore and Clifford decisions.

27 "Where the driver receives a tangible benefit ... which is the motivating influence for furnishing the transportation, the rider is a passenger ...." [Citing Whitmore v. French.] Clifford v. Ruocco, 39 Cal.2d 327, 328, 246 P.2d 651, 652 (1952). The question in issue on appeal was inadequacy of damages, the jury having specially found passenger status. The footnote thus was dictum.

28 Thompson v. Lacey, 42 Cal.2d 443, 267 P.2d 1 (1954); Kroiss v. Butler, 129 Cal. App.2d 550, 277 P.2d 873 (1954); Brandis v. Goldanski, 117 Cal. App.2d 42, 255 P.2d 36 (1953); Harris v. Harfmann, 113 Cal. App.2d 615, 248 P.2d 501 (1952). 
The one exception is Brandis v. Goldanski, ${ }^{2 \theta}$ in which Justice Peters, speaking for the court, discussed the inconsistency of the Clifford and Whitmore wordings, finally holding that compensation can be found where any tangible benefit "is at least a motivating influence for taking the trip."

The most recent case on this point, Martinez v. Southern Pacific Co., ${ }^{31}$ follows the Whitmore wording, citing the $W$ hitmore decision. The McCann case is also cited, ${ }^{31 a}$ however, in a manner not indicative of a belief by the court that any inconsistency exists between the two cases. Thus, the scope of the tangible benefit test is somewhat obscured, and lower courts are in a state of disagreement as to its exact wording.

In Harris v. Harfmann, ${ }^{32}$ plaintiff with her two children accompanied plaintiff's sister, the defendant, and their mother on a motor trip to Oklahoma and return, plaintiff paying for gasoline and oil. Originally, the defendant and her mother were making the trip so that the mother might attend to some property she owned in Oklahoma. When the plaintiff wished to visit her son, she and her two children were included in the party. Though the injuries to plaintiff occured in New Mexico, the court held that the laws of the two states were similar and applied the California cases. The court correctly said that the Whitmore case "states the rule that where the driver receives a tangible benefit ... which is a motivating infiuence for furnishing the transportation, the rider is a passenger and the driver is liable for ordinary negligence." 33

But, the court continued, "where one makes a substantial contribution toward the cost of the journey, as a matter of law he is a passenger and not a guest." 34 The Harris opinion seems to overstate the Whitmore rule in this regard by saying a "substantial contribution" always amounts to conpensation as a matter of law. The Whitmore case only holds that where one reasonable inference alone may be drawn froin the evidence, the judge can decide the factual question as one of law. The Whitmore opinion is in line with other authority that the issue of passenger or guest is one of fact. ${ }^{35}$ A contribution, substantial in amount, could, by the Whitmore rule, not be a motivating factor, but inerely a common courtesy of the road; hence, not compensation.

29117 Cal. App.2d 42, 255 P.2d 36 (1953). Defendant donated his services and truck to further a church picnic. Defendant drove the truckload of equipment while the plaintiff rode along and directed him to the picnic grounds. On the way plaintiff was injured by defendant's ordinary neghigence. Held: in light of the circumstances, a mere incidental courtesy. No compensation existed.

30 Id. at 49,255 P.2d at 40. Simce the court was speaking of "at least a" motivating factor and " $\mathrm{a}$ " is the more inclusive of the two wordings, it would appear that Justice Peters is following the Whitmore wording.

3145 A.C. $268,274,288$ P.2d 868, 871 (1955).

31 Id. at 275,288 P.2d at 871.

32113 Cal. App.2d 615, 248 P.2d 501 (1952).

33 Id. at 616,248 P.2d at 502 .

34 Id. at 617,248 P.2d at 502 .

35 See note 16 supra. 
In summary, the Califormia courts have been liberal in finding compensation, which is alternately defined as a tangible benefit to the driver or owner which is the or $a$ motivating influence for furnishing the transportation. Though more of the subsequent cases pick up the Whitmore language, it is submitted that the McCann v. Hoffman ${ }^{36}$ test is the proper one; i.e., the benefit must be the motivating influence for furnishing the transportation.

The Whitmore wording of the test coupled with the broad definition of compensation would frustrate the legislative purpose. Many of the cases of joint motor trips involve relatives and friends, and represent the very type of suit which induced the legislature to adopt the guest statute in the first place. ${ }^{37}$ Thougl the injured rider who is legitimately a passenger should be protected, the court should not interpret away the guest statute by an over-solicitous penchant for finding compensation.

Donald K. Bjelke

369 Cal.2d 279, 70 P.2d 909 (1937).

37 "[Automobile guest statutes] have been enacted under the impetus of a feeling that the gratuitous guest is entitled to no claim against his host for the ordinary mishaps of modern traffic and under the impetus of the claim of liability insurance companies that frequent collusion between host and guest has increased insurance rates." Prosser, TorTs 451-52 (2d cd. 1955). See also authority cited, $i d$. at 452 n.69. 